\title{
THE 3-D NUMERICAL SIMULATIONS OF THE SMALL RADIUS ACCRETION DISK FORMATION IN MICROQUASAR CYG X-1. THE CASE OF THE HIGH RESOLUTION GRID IN THE VERTICAL DIRECTION
}

\author{
V.V. Nazarenko \\ Astronomical Observatory, Odessa National University, \\ Shevchenko Park, Odessa, 65014, Ukraine, nazaret@te.net.ua
}

ABSTRACT. The present paper is devoted to small radius accretion disk formation in microquasar $\mathrm{CYG}$ $\mathrm{X}-1$. The results show that in the case of the strong wind action on a disk the disk radius is about of $20 \div 30$ per sent of accretor's Roche lobe radius (it is about of 0.08 of orbital separation) instead of the standard disk radius equal to $80 \div 85$ per sent of accretor's Roche lobe radius (the last magnitude is a disk radius equal to 0.22 of orbital separation). In the present paper we try to resolve the problem that is arising in the case of microquasars when we investigate the accretion disk formation in these objects. Indeed, since the microquasars are the massive close binary systems (MCBS) in which the donor is massive stars of O-B class the strong wind is blowing from these stars. In this case the problem is arising: what is the situation in which an accretion disk in microqausars is formed. By the other words, it means what are the processes and the matter that are responsible for an accretion disk formation in microquasars: is this matter from one-point stream only or a disk is formed from the donor's wind in essential or one is formed from both processes simultaneously. This question is not idle since one is strong affects on ON-OFF state generations in the precession mechanism model. Since this mechanism is strong depending from the magnitude of the disk centre density and all the parameters affecting on it are very important for calculations. The matter configuration in the vicinity of one-point is one of these parameters that strong affects on ON-OFF state production and disk structure and the central disk density. By this reason we have investigated in the present paper how the disk structure is depending from the wind configuration in the vicinity of one-point.

АНОТАЦЯ. Представлена стаття присвячена формуванню акреційного диску малого радіусу в мікроквазарі CYG X-1. Результати показують, що у випадку дії сильного вітру на диск, радіус диску становить 20-30\% від радіуса порожнини Роша акретора (це значення дорівнює 0,08 в одиницях орбітальних поділів) замість стандартного значення радіусу диску, рівного $80-85 \%$ радіуса порожнини Роша акретора, що дорівнюе 0,22 в одиницях орбітальних поділів. В даній статті ми намагаємося вирішити проблему, яка виникає у випадку мікроквазарів, коли ми досліджуємо формування акреційного диску в таких об'єктах. Дійсно, мікроквазари $є$ масивними тісними подвійними системами, що мають донором масивну зорю О-В класу, від якої дме сильний вітер. У цьому випадку виникає питання: якою повинна бути ситуація для формування акреційного диску в мікроквазарах. Іншими словами, які процеси та речовина, що відповідають за формування акреційного диску: чи це речовина, що тече тільки в потоці від точки L1, чи диск формується здебільшого із вітру донора, чи у формуванні акреційного диску приймають участь обидва процеси. Таке питання не пусте, оскільки воно дуже впливає на генерацію включених/виключених станів в моделі прецесійного механізму запуску джет. Оскільки цей механізм надто залежить від щільності в центрі диску, то ж всі параметри, що впливають на цю щільність важливі для обчислень. Конфігурація речовини в околиці точки L1 являється одним 3 таких параметрів, який має великий вплив на виникнення включених/виключених станів, структуру диску та щільність в центрі диску. 3 цієї причини в даній статті ми досліджували те, як структура диску залежить від конфігурації вітру в околиці точки L1.

Keywords: Stars: binaries - stars: jets - methods: numerical - hydrodynamics.

\section{Introduction}

The present paper is devoted to the numerical calculations of small radius accretion disk formation in microquasar CYG X-1. A s it is well known the classical 
microquasars are massive close binary systems (CBS) in which donor and accretor are massive super giant of class of O-B and massive black hole respectively. As it is led from stated above the situation in which an accretion disk is formed in microqausar are substantially different from accretion disk formation in usual $\mathrm{X}$-ray binaries. This difference is that in microquasars the strong wind is blowing from donor and this wind is strong pressing an accretion disk. By this reason, for instance, accretion disk in CYG X-1 have the very small radius relatively it normal size for usual accretion disks. The standard disk radius is about of $80 \div 85$ per sent of the accretor's Roche lobe radius because of the donor's tidal effects on the disk. On the other hand the observations of CYG X-1 (Karitskaja E.A., Bochkarev $\mathrm{N}$., private communications) show that the disk radii in this microquasar is the very small and is equal to $0.15 \div 0.20$ in units of the orbital separation. Such the observations directly show on the affection of donor's wind on accretion disk structure in microquasars. By such the way our goal in the present research is to confirm this affections by the method of 3-D numerical hydrodynamics.

The paper have the four section. The first is an introduction. The second is the numerical model description. On the third one we describe our numerical results. The last section is the discuss and conclusions.

\section{The numerical algorithm}

The description of the numerical algorithm in use in details is given in our previous works (Nazarenko \& Nazarenko, 2014, 2015, 2016, 2017; Nazarenko V.V., 2018, 2019, 2020). Shortly, this algorithm is as follows: to resolve the non-stationary Euler's hydrodynamical equations we have used the astrophysical variant of "large-particles" code by Belotserkovskii and Davydov (Belotserkovskii \& Davydov, 1982); to simulate one-point-stream we use the donor's atmosphere model that in turn is constructed on the base Kurucz's grid (Kurucz, 1979) with the donor's parameters; we use the free-flow boundary conditions allowing to a gas to flow freely via the calculation area boundaries; to calculate mass flow real temperature we use the radiation cooling explicitly (Cox\& Daltabuit, 1971). In the present calculation we use the rectangular coordinate system centred on the donor's centre. We have adopted the donor's mass to be equal to 40 solar mass and the accretor's mass to be equal to 10 solar mass. The precession period in the present simulations is about of 8 orbital periods. Hereafter all the distances will be given in units of the orbital separations; the temperature will be given in units of EV; the density will be given in units of $10^{11} \mathrm{~cm}^{-3}$; the times in the figures (see below) are given in units of the precession period. The initial one-point density is equal to 0.3431 . In the present simulations the grid size is equal to $116^{*} 190 * 190$. The cell sizes in orbital plane are equal to 0.00955 and this size in the vertical direction is equal to 0.0815 . The last means that in our present simulations the jets will be launched on highness of 10000 Schwarzschild radiuses.

Accordingly Wijers and Pringle (Wijers R.A.M.J. \& Pringle J.E., 1999) we have choose the mass transfer rate to be equal to $510^{-8}$ solar mass per year. The donor's wind mass lost rate is order of $510^{-4}$ solar mass per year.

\section{The results}



Figure 1: The orbital plane disk structure in the case of the strong wind in the vicinity of one-point

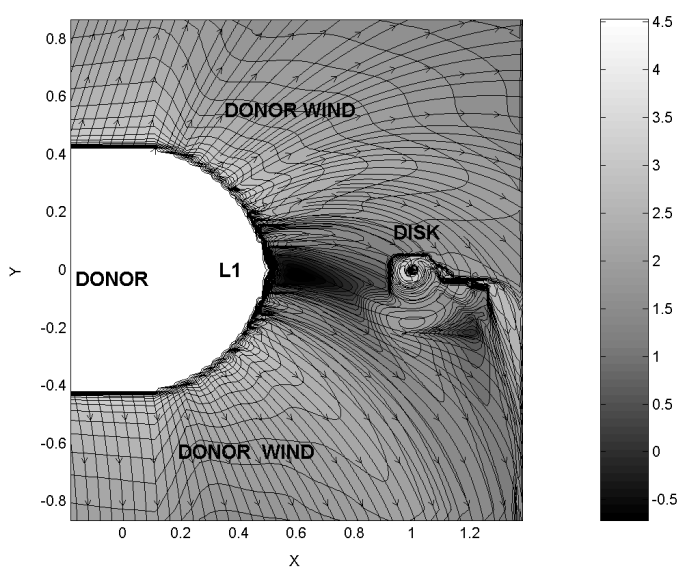

Figure 2: The orbital plane disk structure in flow lines in the case of the strong wind in the vicinity of one-point

The first of the turn we will describe the results of the disk formation for the case of the very narrow 


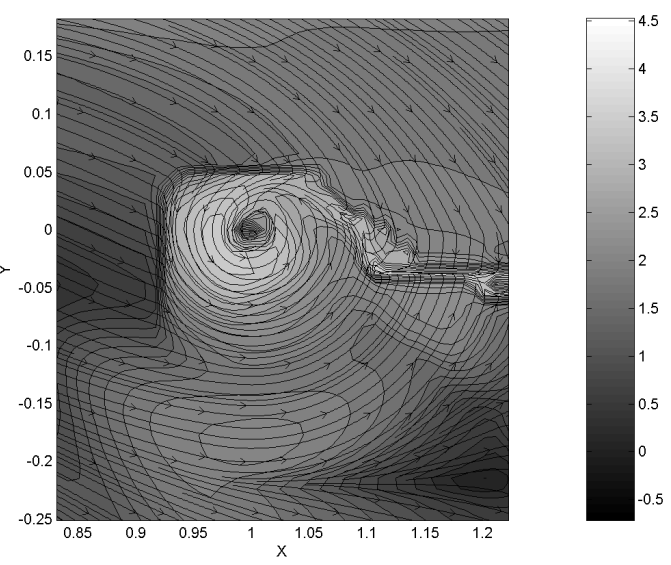

Figure 3: The disk structure in details in flow lines in the case of the strong wind in the vicinity of one-point

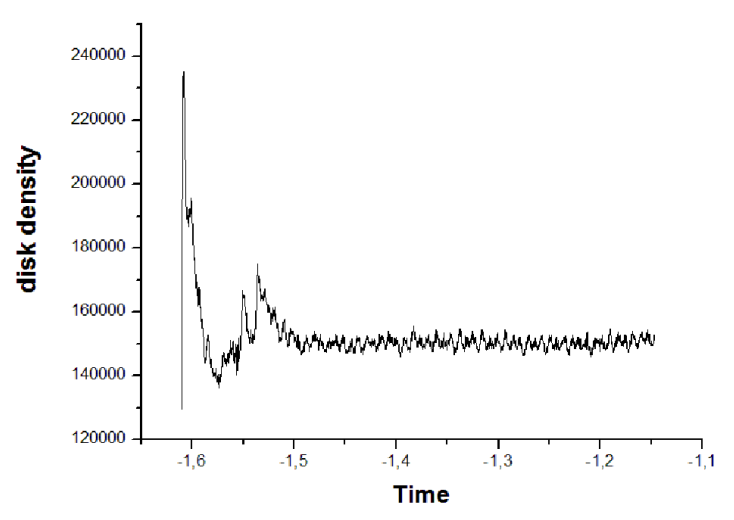

Figure 4: The dependence of the average-volume disk density versus time for the case of strong wind in onepoint

donor's wind in the vicinity of one-point. As the calculations show the stationary state in disk is achieved after first one orbital period of the calculations. The disk structure in the orbital plane is shown in the Fig. 1, Fig. 2 and Fig. 3. In Fig.1 we show the density distribution and velocity field; in Fig. 2 we show the density distributions and flow lines and in Fig. 3 we show flow lines and density in the vicinity of the disk. As it is led from Fig. 1 the one-point stream is absent and the matter is flowing in a disk via the donor's wind only. The disk radius on Fig. 1 is about of 0.08 in scale of the orbital separation. The Fig. 1 also show that the wind in this picture in the vicinity of one-point is very narrow and the wideness of the region in which the wind is absent in the vicinity of one-point is order of 0.05 of the orbital separation. The Fig. 5 show

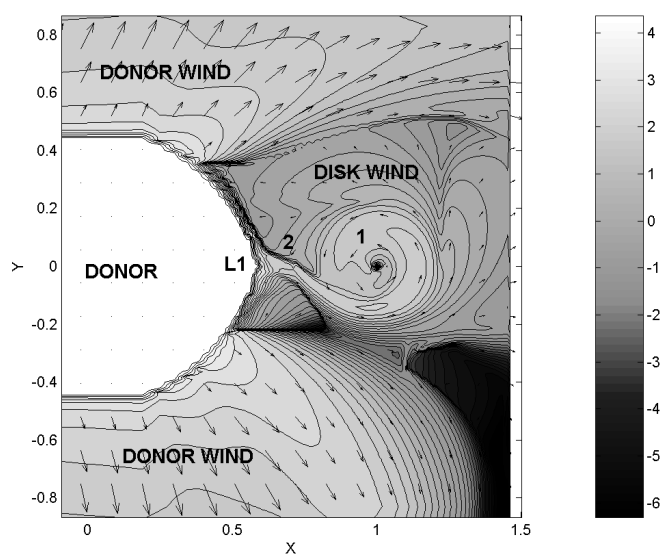

Figure 5: The orbital plane disk structure in the case of the wide wind in the vicinity of one-point

that the disk radius is about of 0.22 when the disk configuration in the vicinity of one-point is wide. Such the way we may see how wind one-point configuration is affecting on the disk structure.

\section{Summary and conclusions}

As the present calculations show, in the case of strong action of the donor's wind on a disk the disk radii is about of $20 \div 30$ per sent of the accretor's Roche lobe radius. On the other hand, when the wind configuration in the vicinity of one-point is the very wide, the disk radii have the standard one.

In the future works we will analyse the influence of the physical parameters (the binary mass transfer rate, the wind configuration, the wind mass lost rate, the disk's viscosity) on the microquasar disk structure variety.

\section{References}

Belotserkovskii O.M., Davydov Yu.M.: 1982, The large particles code in gas dynamics, Moscow: Nauka, 391 .

Cox D. P., Daltabuit E.: 1971, ApJ, 167, 113.

Karitskaja E.A., Bochkarev N., private communications Kurucz, R.L.: 1979, ApJ. Suppl. Ser., 40, 1.

Nazarenko V.V., Nazarenko S.V.: 2014, Odessa Astron. Publ., 27, 137.

Nazarenko V.V., Nazarenko S.V.: 2015, Odessa Astron. Publ., 28, 171.

Nazarenko V.V., Nazarenko S.V.: 2016, Odessa Astron. Publ., 29, 82.

Nazarenko V.V., Nazarenko S.V.: 2017, Odessa Astron. Publ., 30, 113.

Nazarenko V.V.: 2018, Odessa Astron. Publ., 31, 90.

Nazarenko V.V.: 2019, Odessa Astron. Publ., 32, 70.

Nazarenko V.V.: 2020, Odessa Astron. Publ., 33, 45.

Wijers R.A.M.J., Pringle J.E.: 1999, MNRAS, 308, 207. 